Article

\title{
Lithium Hydroxide Reaction for Low Temperature Chemical Heat Storage: Hydration and Dehydration Reaction
}

\author{
Jun $\mathrm{Li}^{1}$, Tao Zeng ${ }^{2}$, Noriyuki Kobayashi ${ }^{1}$, Haotai $\mathrm{Xu}^{1}{ }^{1}$, Yu Bai ${ }^{2}$, Lisheng Deng ${ }^{2}$, \\ Zhaohong $\mathrm{He}^{2, *}$ and Hongyu Huang ${ }^{2, *}$ \\ 1 Department of Chemical Engineering, Nagoya University, Nagoya, Aichi 464-8603, Japan; \\ junli@energy.gr.jp (J.L.); kobayashi@energy.gr.jp (N.K.); xvhaotai@yahoo.co.jp (H.X.) \\ 2 Guangzhou Institute of Energy Conversion, Chinese Academy of Sciences, Guangzhou 510640, China; \\ eric12142@gmail.com (T.Z.); baiyu@ms.giec.ac.cn (Y.B.); dengls@ms.giec.ac.cn (L.D.) \\ * Correspondence: hezh@ms.giec.ac.cn (Z.H.); huanghy@ms.giec.ac.cn (H.H.); \\ Tel.: +86-20-870-48394 (Z.H.); +86-20-870-48394 (H.H.)
}

Received: 6 September 2019; Accepted: 27 September 2019; Published: 30 September 2019

\begin{abstract}
As a key parameter of a chemical heat storage material, the hydration and dehydration reaction characteristics of lithium hydroxide $(\mathrm{LiOH})$ at pure vapor condition is unclear. In this study, we focused on the hydration reaction and dehydration process of $\mathrm{LiOH}$ at the pure vapor condition. The pressure-temperature diagram of $\mathrm{LiOH}$ equilibrium was measured. The hydration and dehydration of $\mathrm{LiOH}$ at various conditions have been experimentally investigated. The results show that the steam diffusion can be greatly enhanced at vacuum condition. A thin layer of $\mathrm{LiOH}$ is uniformly dispersed in the reactor, which can greatly increase the heat transfer between the $\mathrm{LiOH}$ material and reactor, leading to a higher hydration reaction rate of $\mathrm{LiOH}$. Furthermore, the steam pressure, reaction temperature, and the particle size of $\mathrm{LiOH}$ can greatly influence the hydration reaction. A maximum hydration reaction rate of $80 \%$ is obtained under the conditions of $47^{\circ} \mathrm{C}$, steam pressure of $9 \mathrm{kPa}$, and particle size of 32-40 $\mu \mathrm{m}$. LiOH exhibits a different reaction property at the condition of pure steam without air and below atmospheric pressure. A store and reaction condition of $\mathrm{LiOH}$ with isolation of air is recommended when apply $\mathrm{LiOH}$ as a heat storage material at low temperature.
\end{abstract}

Keywords: $\mathrm{LiOH}$; heat storage; low temperature; hydration reaction; dehydration reaction

\section{Introduction}

In order to increase the total energy utilization efficient, the application of thermal energy storage technologies, including sensible heat storage, latent heat storage, and chemical heat storage, have been extensively studied in the recent decades [1-6]. Chemical heat storage shows great advantages with following characteristics $[3,4,6]$ : (1) Chemical heat storage can store and release heat with a relatively high energy density by reversible chemical reaction; (2) chemical heat storage can utilize waste heat during various temperature range by different reaction pairs and selected reaction conditions; and (3) thermal energy can be stored in chemical substances form without any heat loss. The long-term heat storage can be possible in chemical substance form; (4) the chemical heat storage can store and release heat at an arbitrary temperature depending on the reaction equilibrium temperature and pressure.

The chemical heat storage cycle can be divided into the heat storage process and heat release process, which can be repeated with reversible chemical reaction. In each operation, the reaction gas moves between the reactor-evaporation or reactor-condenser by the pressure difference as the driving 
force. A typical reversible thermochemical reaction is shown in Equation 1. The heat storage operation and the heat release process can be summarized as the following Equations [7-10].

$$
\mathrm{AB}(s)\langle=\rangle A(s)+B(g) .
$$

Heat storage process:

$$
\begin{gathered}
\mathrm{AB}(s) \rightarrow A(s)+B(g) ; \Delta H>0 . \\
B(g) \rightarrow B(l) .
\end{gathered}
$$

Heat release process:

$$
\begin{aligned}
A(s)+B(g) & \rightarrow \mathrm{AB}(s) ; \Delta H<0 . \\
B(l) & \rightarrow B(g) .
\end{aligned}
$$

Numerous chemical heat storage materials have been investigated for different temperature ranges. The heat storage temperature and heat storage density of various typical reaction pairs are summarized in Table 1. A wide range of storage temperature can be achieved by applying different reaction systems. For middle and low temperature storage, numerous reaction systems, the metal salts and hydroxide such with vapor [11-16] and ammonia $\left(\mathrm{NH}_{3}\right)[9,17-20]$ systems, have been proposed and investigated. The heat around $200{ }^{\circ} \mathrm{C}$ can be utilized by the reaction pairs of $\mathrm{FeCl}_{2} / \mathrm{NH}_{3}$ (ammonia molecules: 6-2) and $\mathrm{NiCl}_{2} / \mathrm{NH}_{3}(6-2)$ with heat storage of 1620 and $1829 \mathrm{~kJ} / \mathrm{kg}$, or 2560 and 1757 $\mathrm{kJ} / \mathrm{L}$ [9]. The reaction pairs of $\mathrm{MgSO}_{4} / \mathrm{H}_{2} \mathrm{O}$ (7-0.5) [11], $\mathrm{MgCl}_{2} / \mathrm{H}_{2} \mathrm{O}$ (6-2) [14], and $\mathrm{MnCl}_{2} / \mathrm{NH}_{3}$ (6-2) [9] can be charged around $150{ }^{\circ} \mathrm{C}$. Among them, $\mathrm{MgSO}_{4} / \mathrm{H}_{2} \mathrm{O}(7-0.5)$ has a relatively high heat storage density of $2498 \mathrm{~kJ} / \mathrm{kg}$ or $3326 \mathrm{~kJ} / \mathrm{L}$. For low temperature around $50{ }^{\circ} \mathrm{C}$, the reaction pairs of $\mathrm{LiOH} / \mathrm{H}_{2} \mathrm{O}$ (1-0) [16,21,22], $\mathrm{NH}_{4} \mathrm{Cl} / \mathrm{NH}_{3}$ (3-0) [9], $\mathrm{NaBr} / \mathrm{NH}_{4}$ (5.25-0) [9], and $\mathrm{BaCl}_{2} / \mathrm{NH}_{3}$ (8-0) [9] can be applied.

The reaction pair of $\mathrm{LiOH} / \mathrm{LiOH} \cdot \mathrm{H}_{2} \mathrm{O}$ is selected because of relative high heat storage density based on weight. Kubota et al. [16] investigated the enhancement of the hydration rate of $\mathrm{LiOH}$ by combining with mesoporous carbon. The results showed that LiOH could be successfully supported on mesoporous carbon. The hydration reaction rate of $\mathrm{LiOH}$ were increased by combining with mesoporous carbon, which demonstrated that $\mathrm{LiOH}$ supported on mesoporous carbon was an effective method to improve the hydration reaction rate of $\mathrm{LiOH}$. The effect of $\mathrm{LiOH}$ addition on dehydration reaction of $\mathrm{Mg}(\mathrm{OH})_{2}$ has been investigated by Kurosawa and Ryu [23]. They found that the rate of the dehydration reaction could be increased with increasing addition ratio of $\mathrm{LiOH}$. Yang et al. [24] applied carbon nanospheres (CNSs) and multi-walled carbon nanotubes (MWCNTs) to modify LiOH for low temperature chemical heat storage. They obtained high thermochemical composite materials of $\mathrm{LiOH} \cdot \mathrm{H}_{2} \mathrm{O} / \mathrm{CNSs}, \mathrm{LiOH} \cdot \mathrm{H}_{2} \mathrm{O} / \mathrm{MWCNTs}$, and $\mathrm{LiOH} \cdot \mathrm{H}_{2} \mathrm{O} / \mathrm{AC}$ (activated carbon) with heat density of $2020 \mathrm{~kJ} / \mathrm{kg}, 1804 \mathrm{~kJ} / \mathrm{kg}$, and $1236 \mathrm{~kJ} / \mathrm{kg}$, respectively. The effect of addition and modification of LiOH has been widely investigated by previous studies.

As above, the enhancement of $\mathrm{LiOH}$ by various methods has been investigated. It is possible to improve $\mathrm{LiOH}$ performance by those methods. However, the operation conditions of $\mathrm{LiOH} / \mathrm{LiOH} \cdot \mathrm{H}_{2} \mathrm{O}$ pair and hydration/dehydration reaction performance for $\mathrm{LiOH}$ at pure vapor condition remain also unclear and need further investigation. As a key parameter of a chemical heat storage material, the hydration and dehydration reaction of lithium hydroxide $(\mathrm{LiOH})$ at pure vapor condition remains unclear. Thus, the studies on the hydration and dehydration reaction of $\mathrm{LiOH}$ for low temperature chemical heat storage are valuable. This research aims to evaluate the true reaction rate of $\mathrm{LiOH}$ with pure vapor conditions. The operation conditions of $\mathrm{LiOH}$ at hydration and dehydration have been confirmed, the hydration reaction and dehydration reaction rates of $\mathrm{LiOH}$ at various steam pressures, reaction temperatures, and the particle sizes have been investigated. The results can contribute to the fundamental database and provide an in-depth understanding of hydration and dehydration process of $\mathrm{LiOH}$ for low temperature chemical heat storage. 
Table 1. Energy storage density of different materials.

\begin{tabular}{|c|c|c|c|c|c|}
\hline Reference & Reaction Pair * & Description & $\begin{array}{l}\text { Operation } \\
\text { Conditions }\end{array}$ & $\begin{array}{c}\text { Heat Storage } \\
\text { Density (kJ/kg) }\end{array}$ & $\begin{array}{c}\text { Heat Storage } \\
\text { Density }(\mathrm{kJ} / \mathrm{L})\end{array}$ \\
\hline Van Essen et al. [11] & $\begin{array}{c}\mathrm{MgSO}_{4} / \mathrm{H}_{2} \mathrm{O} \\
(7-0.5)\end{array}$ & $\begin{array}{c}\text { Experimental, Open } \\
\text { system, TG }{ }^{\mathrm{a}} \text { and DSC }\end{array}$ & Charging: $150^{\circ} \mathrm{C}$ & 2498 & 3326 \\
\hline Boer et al. [12] & $\begin{array}{l}\mathrm{Na}_{2} \mathrm{~S} / \mathrm{H}_{2} \mathrm{O} \\
(5-0.5)\end{array}$ & Experimental & Charging: $83^{\circ} \mathrm{C}$ & 3841 & 3564 \\
\hline Lahmidi et al. [13] & $\begin{array}{l}\mathrm{SrBr}_{2} / \mathrm{H}_{2} \mathrm{O} \\
\quad(6-1)\end{array}$ & $\begin{array}{c}\text { Experimental, } \\
\text { Consolidated } \mathrm{SrBr}_{2} \text { with } \\
\text { expanded graphite }\end{array}$ & Charging: $80^{\circ} \mathrm{C}$ & 900 & 630 \\
\hline Zondag et al. [14] & $\underset{(6-2)}{\mathrm{MgCl}_{2} / \mathrm{H}_{2} \mathrm{O}}$ & Experimental, DSC & Charging: $130^{\circ} \mathrm{C}$ & 1717 & 2002 \\
\hline Ferchaud [15] & $\begin{array}{c}\mathrm{Li}_{2} \mathrm{SO}_{4} / \mathrm{H}_{2} \mathrm{O} \\
(0-1)\end{array}$ & Experimental & Charging: $103^{\circ} \mathrm{C}$ & 457 & 943 \\
\hline Kubota el al. [16] & $\begin{array}{l}\mathrm{LiOH} / \mathrm{H}_{2} \mathrm{O} \\
(1-0)\end{array}$ & Experimental & Charging: $64^{\circ} \mathrm{C}$ & 1440 & 950 \\
\hline Li et al. [9] & $\begin{array}{l}\mathrm{NH}_{4} \mathrm{Cl} / \mathrm{NH}_{3} \\
(3-0)\end{array}$ & $\begin{array}{c}\text { Theoretical without } \\
\text { sensible heat charging at } \\
1167 \mathrm{kPa}\end{array}$ & Charging: $48^{\circ} \mathrm{C}$ & 1652 & 1264 \\
\hline - & $\begin{array}{l}\mathrm{NaBr} / \mathrm{NH}_{3} \\
(5.25-0)\end{array}$ & - & Charging: $51^{\circ} \mathrm{C}$ & 1804 & 2887 \\
\hline - & $\begin{array}{c}\mathrm{BaCl}_{2} / \mathrm{NH}_{3} \\
(8-0)\end{array}$ & - & Charging: $56^{\circ} \mathrm{C}$ & 1469 & 2833 \\
\hline - & $\begin{array}{c}\mathrm{SrCl}_{2} / \mathrm{NH}_{3} \\
(8-1)\end{array}$ & - & Charging: $96^{\circ} \mathrm{C}$ & 1832 & 2794 \\
\hline- & $\begin{array}{c}\mathrm{CaCl}_{2} / \mathrm{NH}_{3} \\
(8-1)\end{array}$ & - & Charging: $99^{\circ} \mathrm{C}$ & 2243 & 2423 \\
\hline- & $\begin{array}{c}\mathrm{MnCl}_{2} / \mathrm{NH}_{3} \\
(6-2)\end{array}$ & - & Charging: $152^{\circ} \mathrm{C}$ & 1508 & 2246 \\
\hline- & $\begin{array}{l}\mathrm{FeCl}_{2} / \mathrm{NH}_{3} \\
(6-2)\end{array}$ & - & Charging: $186^{\circ} \mathrm{C}$ & 1620 & 2560 \\
\hline- & $\begin{array}{l}\mathrm{NiCl}_{2} / \mathrm{NH}_{3} \\
\quad(6-2)\end{array}$ & - & Charging: $259^{\circ} \mathrm{C}$ & 1829 & 1757 \\
\hline
\end{tabular}

${ }^{*}$ The number of water or ammonia molecules in the complexes was shown in parentheses. ${ }^{a}$ TG represents thermal gravity; ${ }^{\mathrm{b}}$ DSC represents differential scanning calorimetry.

\section{Experimental Apparatus and Method}

\subsection{The Constant Volume Method}

The constant volume method was applied in this study. The experimental diagram for the constant volume method is shown in Figure 1. A reactor (volume: $0.005 \mathrm{~L}$, initial temperature: $47^{\circ} \mathrm{C}$ ), a reserve tank (temperature $55^{\circ} \mathrm{C}$, capacity $13 \mathrm{~L}$ ), a vacuum pump (ULVAC Kiko, Inc., GLD-051 type), and an evaporator (plate heat-exchange evaporator. Length: $320 \mathrm{~mm}$; width: $100 \mathrm{~mm}$; and thickness: $40 \mathrm{~mm}$ ) were involved. The temperature of the reactor and evaporator were controlled by the thermostatic bath. $\mathrm{LiOH}$ (Kishida Chemical, purity: 98\%) was used as the heat storage material in this research. To reduce heat transfer resistance during the reaction process, $\mathrm{LiOH}$ was filled in the reactor with a tiny thin layer thickness of $0.2-0.3 \mathrm{~mm}$, as shown in Figure 2. In order to keep vacuum state of $\mathrm{LiOH}$ or $\mathrm{LiOH} \cdot \mathrm{H}_{2} \mathrm{O}$ before the reaction, air in the reactor and pipeline was driven away by the vacuum pump. The initial pressure in the reserve tank was set by the evaporator pressure and the vacuum pump, which varied as 3, 5, 7, and $9 \mathrm{kPa}$. The steam was injected into the reactor from evaporator, and then the reaction started. The pressure change in the reactor and reserve tank could be obtained. The reaction rate could be calculated by the steam pressure change in the reserve tank, as shown in Equation (6).

$$
X=\frac{P_{0}-P_{i}}{\Delta \mathrm{P}}
$$

where, $\mathrm{X}(-)$ is the reaction rate, and $\Delta \mathrm{P}(\mathrm{kPa})$ is the theory maximum pressure change, which can be calculated from the weight of $\mathrm{LiOH}$ and reaction equation. $P_{0}(\mathrm{kPa})$ is the initial steam pressure in tank. $P_{i}(\mathrm{kPa})$ is defined as the steam pressure in the tank during the reaction process. 


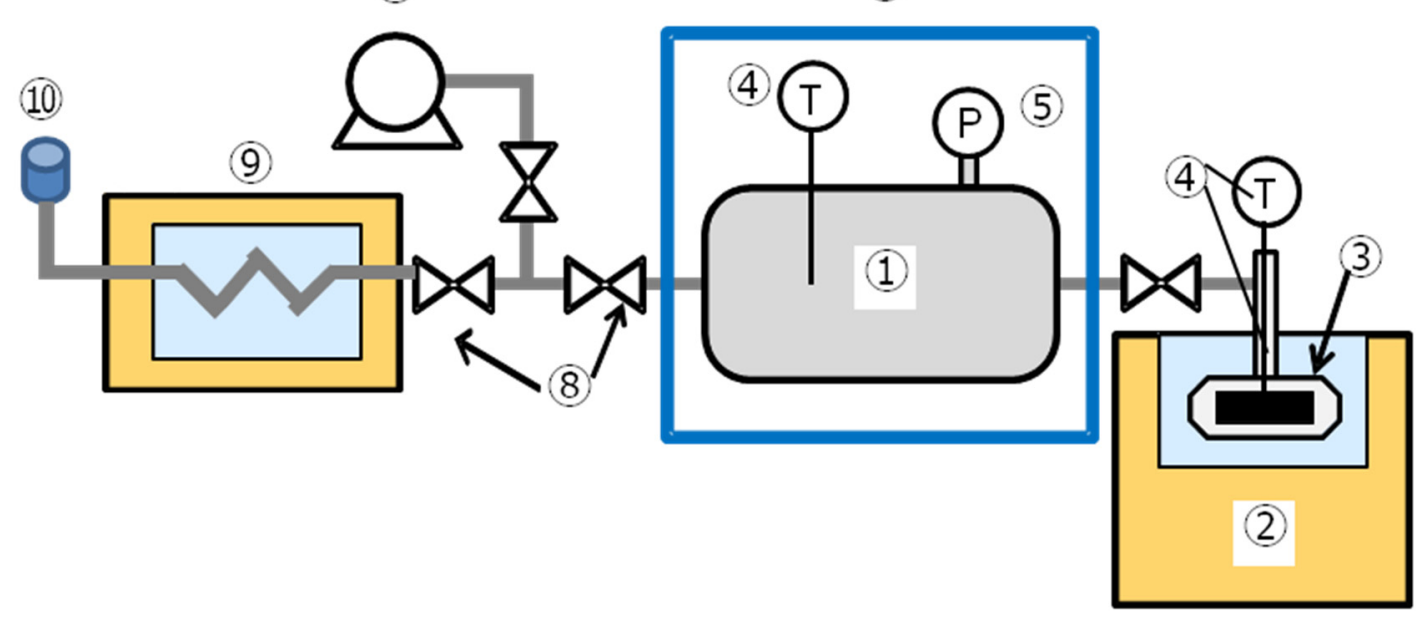

Figure 1. Experimental diagram for the constant volume method. (1) Reserve tank; (2) thermostat bath; (3) reactor; (4) thermocouple; (5) pressure gauge; (6) thermostatic chamber; (7) vacuum pump; (8) valve; (9) evaporator; (10) water tank.

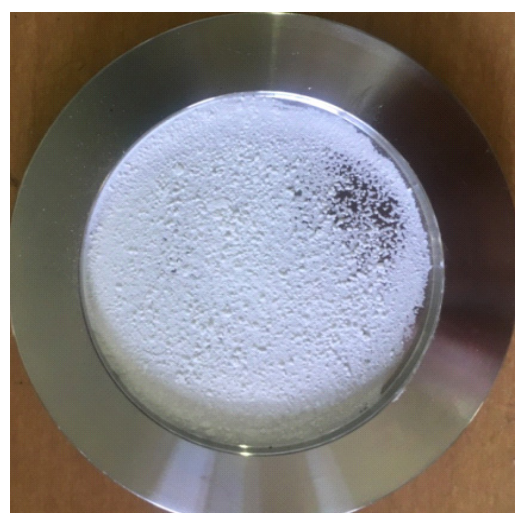

Figure 2. $\mathrm{LiOH}$ in the flat reactor (particle diameter of 32-40 $\mu \mathrm{m}, 0.2-0.3 \mathrm{~mm}$ thickness of packing layer, and $120 \mathrm{mg}$ weight).

\subsection{Hydration Reaction Procedure}

The hydration reaction procedure of $\mathrm{LiOH}$ is summarized as follows: (1) The anhydrous $\mathrm{LiOH}$ samples are taken from the sample bottle, and then the particle diameter is adjusted by a pestle; (2) the anhydrous $\mathrm{LiOH}$ sample is placed in the reactor, and benzine (benzine can make the $\mathrm{LiOH}$ particles uniformly distributed without dissolution. That will not change the particle size of $\mathrm{LiOH}$. The boiling point of benzene is low, which can be easily evaporated) was applied to uniform the $\mathrm{LiOH}$ distribution in the reactor; (3) the reactor is sealed into the thermostat bath and connected with steam pipeline by connecting devices; (4) thermostat bath temperature is set at $80{ }^{\circ} \mathrm{C}$, and the pressure in the thermostatic chamber and the reactor can be driven to the nearly vacuum state of $10 \mathrm{~Pa}$ by the vacuum pump for about $1 \mathrm{~h}$; and (5) the valve between the vacuum pump and reactor is closed; then the valve between the evaporator and reserve tank is opened and the steam is injected into the reserve tank. The steam pressure in the reserve tank can be adjusted by the evaporator. At the same time, the thermostat bath temperature in which the reactor was located is adjusted to the required reaction temperature until the reactor temperature and reserve tank pressure increase to a constant reaction condition before the next step; (6) the electronic valve between the reserve tank and reactor is then opened and the hydration reaction begins with the injection of steam into the reactor. The pressure and temperature changes are recorded with a step of 1 second. During the reaction process, the temperature change is not discussed, because the temperature changes of the $\mathrm{LiOH}$ sample in the reactor is very tiny. The highest 
temperature changes record is approximately $0.5^{\circ} \mathrm{C}$, which cannot be applied to calculate the reaction rate. The effects of hydration temperature, particle size, and steam temperature on hydration reaction rate were investigated. The reaction condition is shown in Table 2.

Table 2. Hydration reaction conditions.

\begin{tabular}{cccc}
\hline Group & Temperature $\left({ }^{\circ} \mathbf{C}\right)$ & Particle Size $(\boldsymbol{\mu m})$ & Steam Pressure $(\mathbf{k P a})$ \\
\hline A & 47 & $32-45$ & 9 \\
B & 50 & $32-45$ & 9 \\
C & 47 & $100-125$ & 6 \\
D & 47 & $100-125$ & 9 \\
\hline
\end{tabular}

\subsection{Dehydration Reaction Procedure}

After hydration reaction, the reacted $\mathrm{LiOH} \cdot \mathrm{H}_{2} \mathrm{O}$ was applied for the dehydration reaction process. The dehydration reaction procedure was followed by the end of hydration reaction and summarized as follows: (1) The value between reactor and reserve tank was closed. In order to ensure the completion of hydration reaction, the vapor pressure and temperature of the reaction were maintained at $9 \mathrm{kPa}$ and $47^{\circ} \mathrm{C}$ for 1 day, respectively; (2) the reserve tank pressure was changed to the dehydration condition of $6 \mathrm{kPa}$; and (3) the valve between reserve tank and reactor was opened, and then the dehydration reaction temperature was increased to $90^{\circ} \mathrm{C}$. The pressure and temperature changes were recorded with a step of 1 second, the same with the hydration reaction process. (4) The same material was measured three times by repeat of the hydration and dehydration procedures.

\section{Discussion}

\subsection{Pressure-Temperature Diagram of $\mathrm{LiOH}$}

During the measurement of the pressure-temperature diagram of $\mathrm{LiOH}$, the pressure-temperature diagram of hydration was firstly measured. The results of the hydration reaction process were measured and shown in Figure 3. For the hydration reaction, the reserve tank and the reactor were pumped to below $10 \mathrm{~Pa}$, and the initial temperature of the reactor was set at $80^{\circ} \mathrm{C}$ during pumping period. Then the steam at the required pressure was injected into the reactor. The temperature of reactor was decreased at $0.025^{\circ} \mathrm{C} / \mathrm{min}$ to find the beginning reaction temperature of the hydration reaction process. The beginning hydration temperature could be considered at where a sharp decline in pressure was. The temperature and pressure at the sharp decline point were considered as the equilibrium temperature and the equilibrium pressure of the hydration reaction process.

After the end of the hydration reaction, the pressure-temperature diagram of dehydration was then measured. The results of the dehydration reaction process were measured and shown in Figure 4. $\mathrm{LiOH}$ was converted to $\mathrm{LiOH} \cdot \mathrm{H}_{2} \mathrm{O}$ after the hydration reaction process, which could be used for the next measurement of the dehydration reaction equilibrium. The steam pressure in the reactor would be kept at $7.7 \mathrm{kPa}$, and the temperature was increased at $0.025^{\circ} \mathrm{C} / \mathrm{min}$ to find the beginning reaction temperature of dehydration. The beginning dehydration temperature could be judged at where a rapid increase in pressure was. The temperature and pressure at the sharp decline point were considered as the equilibrium temperature and pressure of the dehydration reaction process. 


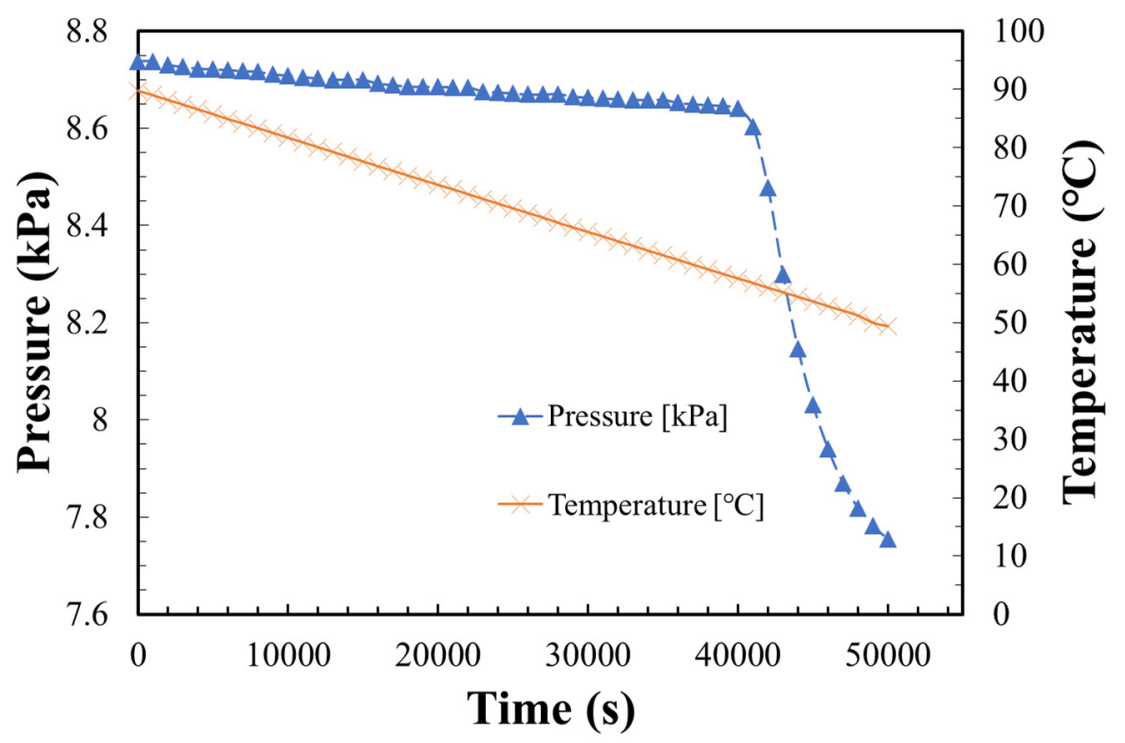

Figure 3. Pressure and temperature change in the measurement of the hydration reaction.

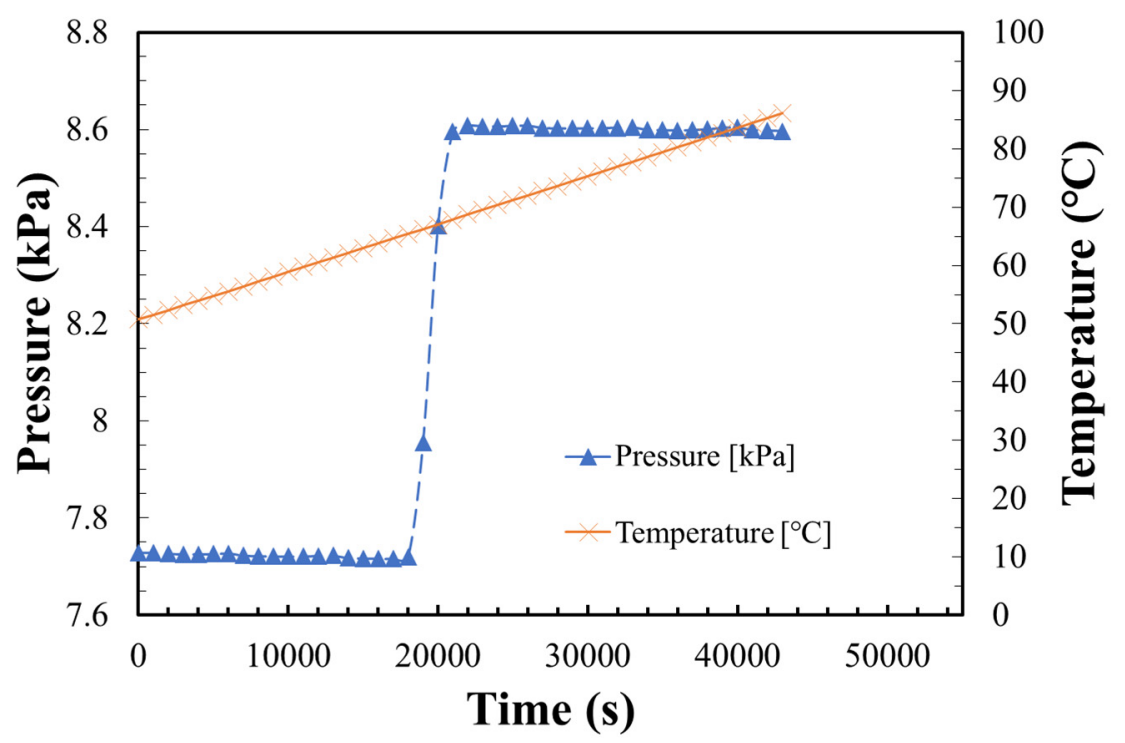

Figure 4. Pressure and temperature change in the measurement of the dehydration reaction.

The equilibrium temperature at the initial pressures of 7,5,3, and $1 \mathrm{kPa}$ were measured by the same method. The measurement results together with the measurement results for the dehydration reaction process by thermal gravity method (TG) [25] and the theoretical equilibrium line of $\mathrm{LiOH}$ [26] are shown in Figure 5. In order to confirm the accuracy of measurements, the measurements of hydration temperature at $35^{\circ} \mathrm{C}$ and dehydration temperature at $50{ }^{\circ} \mathrm{C}$ were measured twice. The hydration pressures were 3 and $2.9 \mathrm{kPa}$ at hydration temperature at $35^{\circ} \mathrm{C}$, while dehydration pressures were 2.77 and $2.8 \mathrm{kPa}$, respectively, which shows a good accuracy of the measurement in this research. As the results shown in Figure 5, the hydration and dehydration temperature could be as low as $20^{\circ} \mathrm{C}$ to $30{ }^{\circ} \mathrm{C}$, which confirms that it was available to apply the $\mathrm{LiOH} / \mathrm{LiOH} \cdot \mathrm{H}_{2} \mathrm{O}$ reaction process for heat storage at a temperature of $20^{\circ} \mathrm{C}$ to $30^{\circ} \mathrm{C}$. Furthermore, the required saturated vapor pressure was higher than the theoretical equilibrium pressure. In the hydration reaction, the hydration equilibrium temperatures at $8.6 \mathrm{kPa}$ and $3 \mathrm{kPa}$ were $55^{\circ} \mathrm{C}$ and $35^{\circ} \mathrm{C}$, which was $25^{\circ} \mathrm{C}$ and $30^{\circ} \mathrm{C}$ lower than the theoretical equilibrium temperature. In the dehydration reaction, the dehydration equilibrium temperatures at $2.77 \mathrm{kPa}$ and $7.7 \mathrm{kPa}$ were $50^{\circ} \mathrm{C}$ and $63^{\circ} \mathrm{C}$, which was $10^{\circ} \mathrm{C}$ and $17^{\circ} \mathrm{C}$ lower than the theoretical equilibrium temperatures. The experimental value was the difference with the previous 
experiment results and theoretical results. The reason could be considered that pressure-temperature diagram was measured under vacuum conditions. The reactant could be considered as the pure vapor without air, which was different from the previous conditions (at atmosphere air condition). Furthermore, the theoretical equilibrium line of $\mathrm{LiOH}$ [26] was calculated at atmosphere air condition. The measurements were carried out under vacuum condition. The dehydrated vapor could be easily escaped, leading to a lower dehydration temperature. Therefore, the dehydration reaction temperature was available at the lower temperature side of the theoretical equilibrium line. LiOH exhibited a different reaction property with pure vapor steam at the vacuum condition compared with that at air conditions. The store condition of $\mathrm{LiOH}$ should be carefully considered in air conditions when applying $\mathrm{LiOH}$ as a heat storage material at low temperature.



Figure 5. Results of the equilibrium line of $\mathrm{LiOH}$ (compared with results from the thermal gravity method [25] and theoretical equilibrium in the previous study [26]).

\subsection{Hydration Reaction Rate of $\mathrm{LiOH}$}

The hydration reaction rate at the particle diameter of 100-125 $\mu \mathrm{m}$, steam pressure of $5 \mathrm{kPa}$, and temperature of $47^{\circ} \mathrm{C}$ was measured by the constant volume method. The measurement results together with the previous study by TG [27] are shown in Figure 6. The difference of the measurement condition is that the previous study was measured by a TG under air conditions. As shown in Figure 6, the reaction rate raised to about $30 \%$ within 1 min of the reaction, which was significantly faster than the previous research. The reason could be considered as an enhancement of heat transfer and steam diffusion in this research. The sealed reactor at the vacuum condition could greatly promote steam diffusion. Furthermore, a thin layer of $\mathrm{LiOH}$ was uniformly dispersed in the reactor, which could greatly increase the heat transfer between the $\mathrm{LiOH}$ material and reactor, leading to a higher hydration reaction rate of $\mathrm{LiOH}$. 


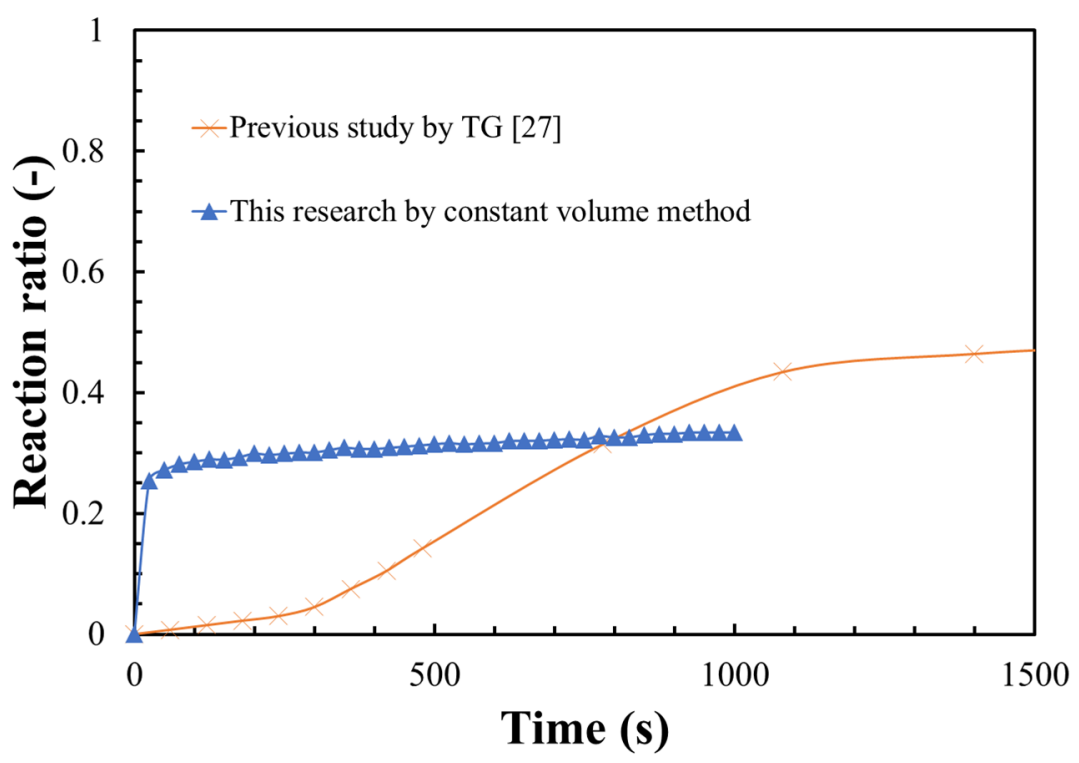

Figure 6. $\mathrm{LiOH}$ hydration reaction (temperature $47^{\circ} \mathrm{C}$, steam pressure $5 \mathrm{kPa}$, and particle size $100-125 \mu \mathrm{m}$ ) with that by the thermal gravity method (TG) [27].

The hydration reaction rates at the particle diameters of 32-40 $\mu \mathrm{m}$ and 100-125 $\mu \mathrm{m}$, steam pressure of $6 \mathrm{kPa}$ and $9 \mathrm{kPa}$, and reactor temperature of $47^{\circ} \mathrm{C}$ and $50^{\circ} \mathrm{C}$ are measured and shown in Figures 7-9, respectively. As can be seen from Figures 7-9, the reaction rate of hydration could not reach $100 \%$ at different conditions of the particle diameter, steam pressure, and reaction temperature. The hydration reaction began with an extremely fast reaction rate in a short period of time, and then the reaction rate continued to increase with a very slow speed, which could be that resistance of the mass transfer in $\mathrm{LiOH}$ particle increased with the progress of the $\mathrm{LiOH}$ hydration reaction. Therefore, it became difficult for the steam to get into the dipper layer of $\mathrm{LiOH}$, leading to a lower reaction rate with time. The hydration reaction time shown in Figure 7 was just $600 \mathrm{~s}$, while the actual measurement time was 3 days. The hydration reaction rate at the particle diameter of $32-40 \mu \mathrm{m}$ could be rapidly reached to $80 \%$ within 5 minutes. While the hydration reaction rate at the particle diameter of $100-125 \mu \mathrm{m}$ reached $60 \%$ at about $600 \mathrm{~s}$. However, the hydration reaction rate at this condition would continue to increase slowly and reach $80 \%$. With the decreasing of the particle diameters, the hydration reaction rate could be accelerated because of a higher diffusion rate between steam and the reaction surface area of $\mathrm{LiOH}$. Furthermore, the surface area of $\mathrm{LiOH}$ at a lower particle diameter was higher, leading to more reaction of $\mathrm{LiOH}$ with steam at the same reaction time. With the increase of steam pressure, steam diffused faster to the surface and inner of $\mathrm{LiOH}$ particles, leading to a higher hydration reaction rate as shown in Figure 8. The hydration reaction was an exothermic reaction, the increase of the reaction temperature was unfavorable to the hydration progress, resulting in a lower hydration reaction rate of LiOH. In Figures 6-9, all experiments were carried out at vacuum condition. The pure vapor could be considered as a reactant because of lacking air. No air was injected in the reactor. Therefore, there was no such influence on the equilibrium of $\mathrm{LiOH}$ hydration/dehydration. The upper limit of the hydration reaction ratio of $\mathrm{LiOH}$ is dependent on the carbonation reaction of $\mathrm{LiOH}$ at the atmosphere air condition [28], because the sub reaction of $\mathrm{LiOH}$ can be active with $\mathrm{CO}_{2}$ at the atmosphere air condition, leading to the conversion of $\mathrm{LiOH}$ to $\mathrm{Li}_{2} \mathrm{CO}_{3}$ [28]. 


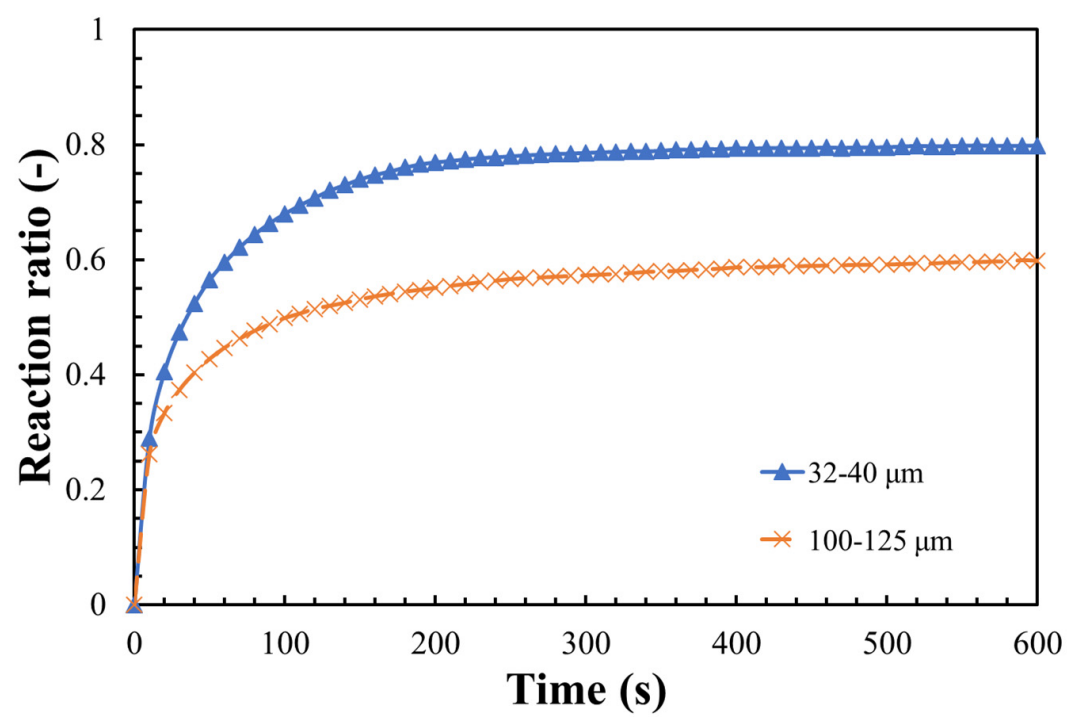

Figure 7. Effect of the particle size on the hydration reaction rate (conditions A and D).

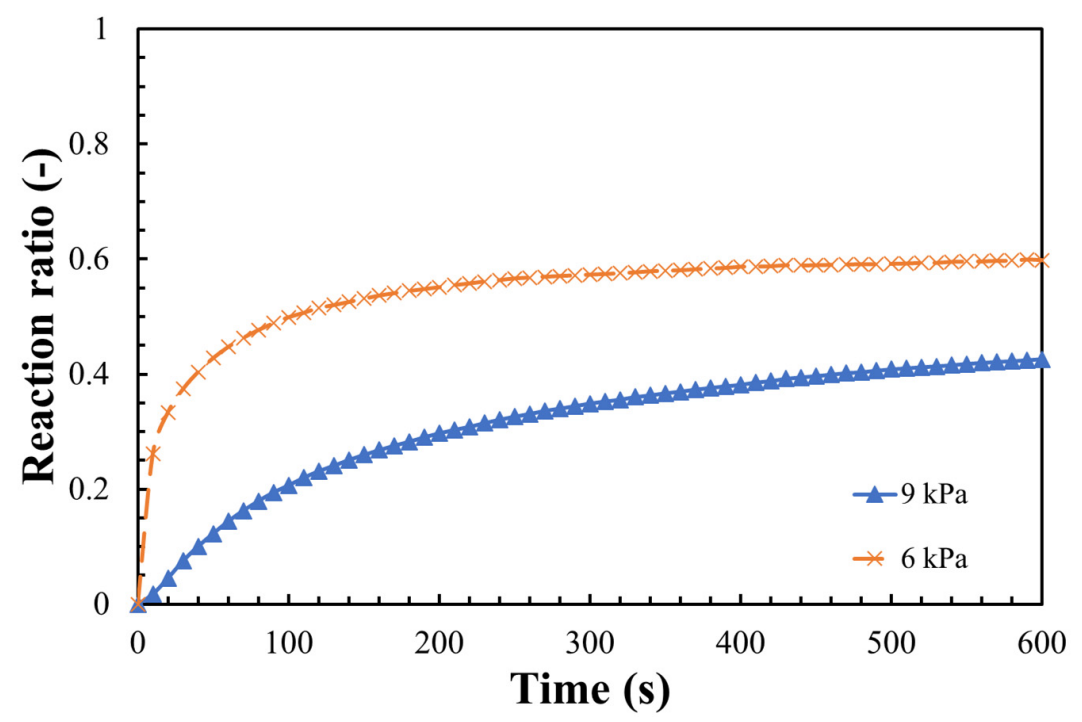

Figure 8. Effect of steam pressure on the hydration reaction rate (conditions $C$ and D).

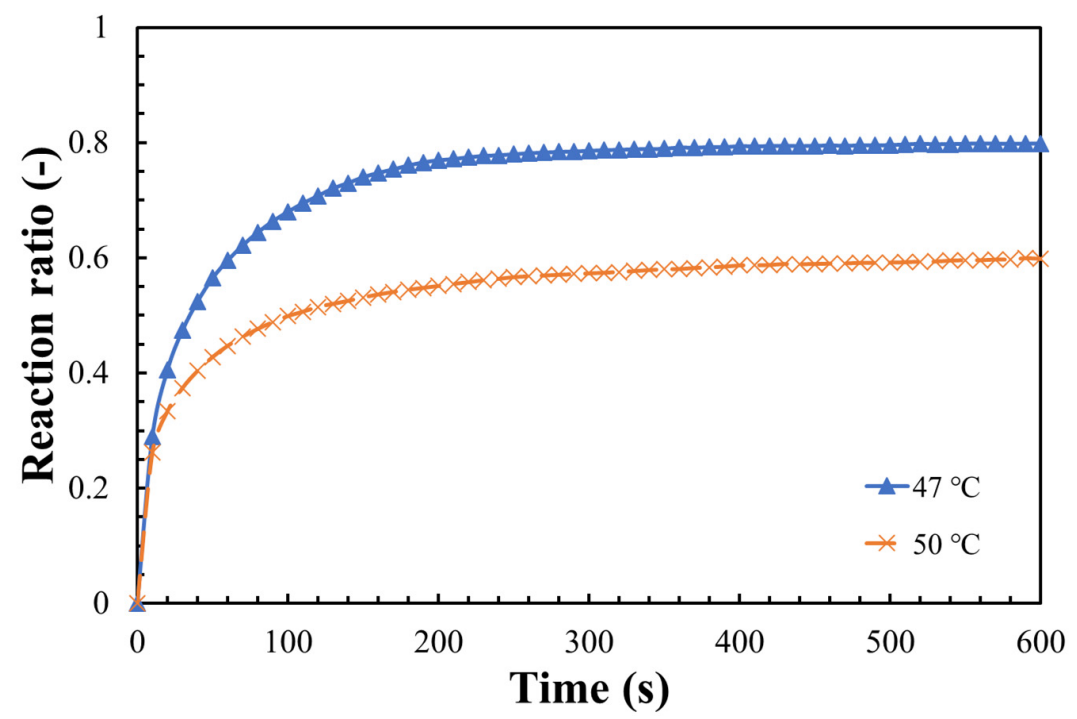

Figure 9. Effect of temperature on the hydration reaction rate (conditions A and B). 


\subsection{Dehydration Reaction Rate of $\mathrm{LiOH}$}

The dehydration reaction was then started after the completion of the hydration reaction at condition A. The result of dehydration is shown in Figure 10. At the start of the measurement, the pressure and temperature are $6 \mathrm{kPa}$ and $47^{\circ} \mathrm{C}$, which had not yet reached the dehydration reaction condition as shown in Figure 5. Therefore, the dehydration reaction rate kept being $0 \%$ for a while. The dehydration reaction started with a rapid pressure increase when the temperature in $\mathrm{LiOH} \cdot \mathrm{H}_{2} \mathrm{O}$ rose to around $58{ }^{\circ} \mathrm{C}$. The pressure stopped changing and the dehydration increased to about $80 \%$ at 10 minutes, which could be considered as the completion of the dehydration reaction. Compared with the hydration reaction, the dehydration reaction could be completed in a very short time. Therefore, the rapid dehydration reaction rate was attractive during the practical application of $\mathrm{LiOH} / \mathrm{LiOH} \cdot \mathrm{H}_{2} \mathrm{O}$ pair for low temperature heat storage.

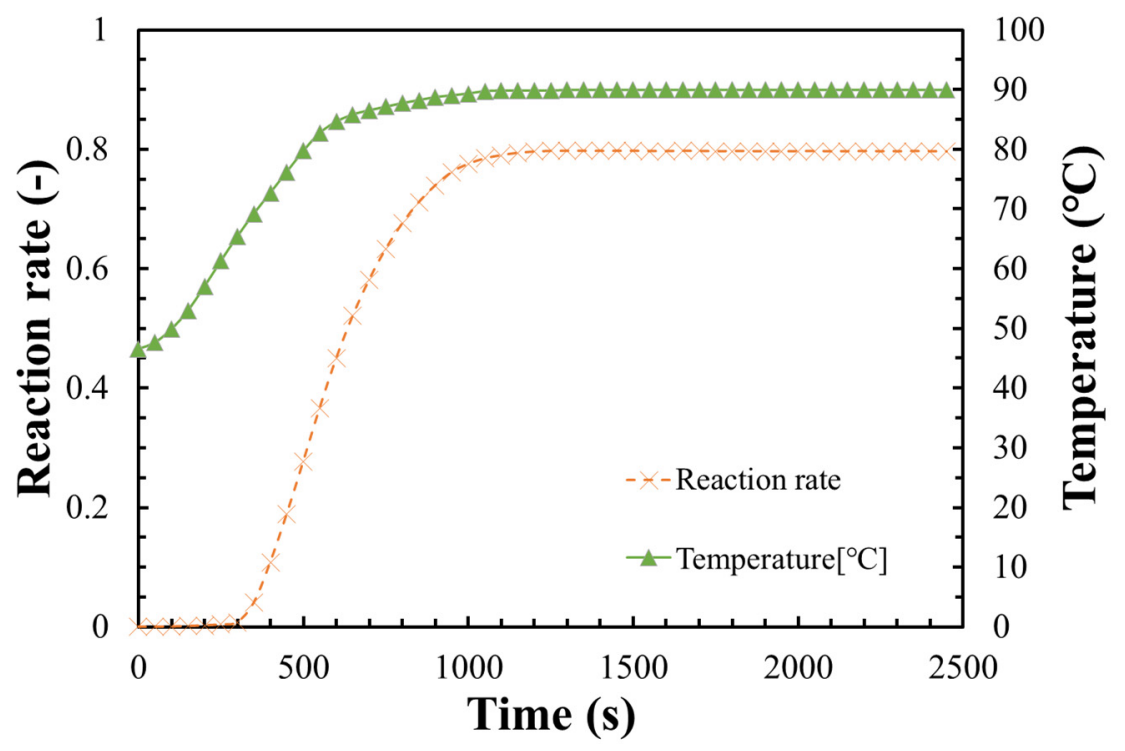

Figure 10. Dehydration reaction rate of $\mathrm{LiOH} \bullet \mathrm{H}_{2} \mathrm{O}$.

The structures of $\mathrm{LiOH}$ after the hydration and dehydration reaction process were observed by SEM (JEOL Ltd., JSM-7800F), which is shown in Figure 11. The SEM photo in Figure 11a shows the result of raw material, Figure $11 \mathrm{~b}, \mathrm{c}$ show that after the hydration and dehydration reactions. The porous channel for steam transfer on the $\mathrm{LiOH}$ surface as shown in Figure $11 \mathrm{~b}, \mathrm{c}$ were increased clearly after the hydration and dehydration reaction process, which could be considered from expansion with the steam getting into/out of the particles during the reaction process. The porous channels in Figure 11b,c were almost the same after the hydration and dehydration reaction at different conditions. Therefore, the diffusion of steam between the surface and inside of $\mathrm{LiOH}$ could be maintained. 


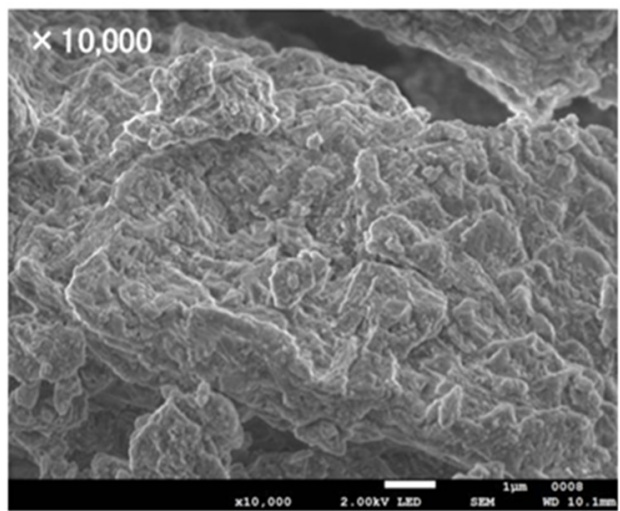

(a)

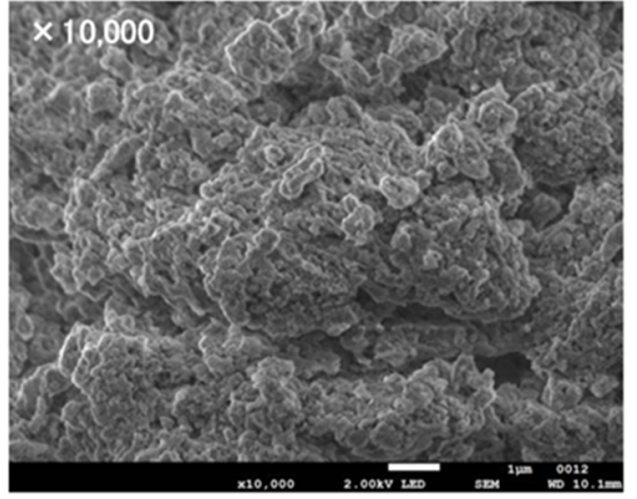

(b)

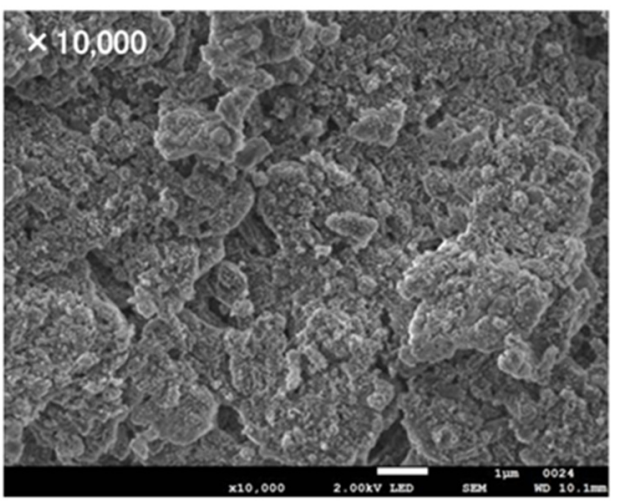

(c)

Figure 11. SEM images: (a) Particle size of LiOH 32-45 um before the reaction; (b) LiOH after the reaction of hydration $47^{\circ} \mathrm{C}, 3 \mathrm{kPa}$ and dehydration $\left(80^{\circ} \mathrm{C}\right.$ vacuum for $24 \mathrm{~h}$ ); and (c) $\mathrm{LiOH}$ after the reaction of hydration at $47^{\circ} \mathrm{C}, 5 \mathrm{kPa}$ and dehydration $\left(80^{\circ} \mathrm{C}\right.$ vacuum for $\left.24 \mathrm{~h}\right)$.

\section{Conclusions}

As a key parameter of a chemical heat storage material, the hydration and dehydration reaction of lithium hydroxide $(\mathrm{LiOH})$ at pure vapor condition was focused on in the research. The pressure-temperature diagram of $\mathrm{LiOH}$ equilibrium was measured. The hydration and dehydration of $\mathrm{LiOH}$ at various conditions were experimentally investigated. The main results were summarized as follows.

1. The measurements of the dehydration reaction were carried out under vacuum condition. The dehydrated vapor could be easily escaped, leading to a lower dehydration temperature compared with the theoretical equilibrium line at atmosphere air condition;

2. The steam diffusion could be greatly enhanced at vacuum condition. A thin layer of $\mathrm{LiOH}$ was uniformly dispersed in the reactor, which could greatly increase the heat transfer between the $\mathrm{LiOH}$ material and reactor, leading to a higher hydration reaction rate of $\mathrm{LiOH}$;

3. The steam pressure, reaction temperature, and the particle size of $\mathrm{LiOH}$ could greatly influence the hydration reaction. A maximum hydration reaction rate of $80 \%$ was obtained under the conditions of $47^{\circ} \mathrm{C}$, steam pressure of $9 \mathrm{kPa}$, and particle size 32-40 $\mu \mathrm{m}$;

4. $\mathrm{LiOH}$ exhibited a different reaction property with pure steam at vacuum condition. The store and reaction conditions of $\mathrm{LiOH}$ should be carefully considered in air conditions when applying $\mathrm{LiOH}$ as a heat storage material at low temperature.

Author Contributions: J.L. contributed to the experiment, data analysis and paper writing; T.Z., H.X., L.D., Z.H. contributed to the experiment and data analysis. H.H., Y.B. and N.K. contributed to experimental design and instruction. 
Funding: This work was supported by "Knowledge Hub Aichi", Priority Research Project from Aichi Prefectural Government, Japan, Leading Key Projects of Chinese Academy of Sciences (No. QYZDY-SSW-JSC038), and Science and Technology Planning Project of Guangdong Province, China (No. 2017A050501046).

Conflicts of Interest: The authors declare no conflict of interest.

\section{References}

1. Li, G. Sensible heat thermal storage energy and exergy performance evaluations. Renew. Sustain. Energy Rev. 2016, 53, 897-923. [CrossRef]

2. Zeinelabdein, R.; Omer, S.; Gan, G. Critical review of latent heat storage systems for free cooling in buildings. Renew. Sustain. Energy Rev. 2018, 82, 2843-2868. [CrossRef]

3. Yan, T.; Wang, R.; Li, T.; Wang, L.; Fred, I. A review of promising candidate reactions for chemical heat storage. Renew. Sustain. Energy Rev. 2015, 43, 13-31. [CrossRef]

4. Saha, B.; Uddin, K.; Pal, A.; Thu, K. Emerging sorption pairs for heat pump applications: An overview. JMST Adv. 2019, 1, 161-180. [CrossRef]

5. Alva, G.; Lin, Y.; Fang, G. An overview of thermal energy storage systems. Energy 2018, 144, $341-378$. [CrossRef]

6. Alva, G.; Lin, Y.; Huang, X.; Fang, G. Thermal energy storage materials and systems for solar energy applications. Renew. Sustain. Energy Rev. 2017, 68, 693-706. [CrossRef]

7. Yu, N.; Wang, R.; Wang, L. Sorption thermal storage for solar energy. Prog. Energy Combust. Sci. 2013, 39, 489-514. [CrossRef]

8. Scapino, L.; Zondag, H.; Bael, J.; Diriken, J.; Rindt, C. Energy density and storage capacity cost comparison of conceptual solid and liquid sorption seasonal heat storage systems for low-temperature space heating. Renew. Sustain. Energy Rev. 2017, 75, 1314-1331. [CrossRef]

9. Li, T.; Wang, R.; Kiplagat, J. A target-oriented solid-gas thermochemical sorption heat transformer for integrated energy storage and energy upgrade. AIChE J. 2013, 59, 1334-1347. [CrossRef]

10. Donkers, P.; Sögütoglu, L.; Huinink, H.; Fischer, H.; Adan, O. A review of salt hydrates for seasonal heat storage in domestic applications. Appl. Energy 2017, 45-68. [CrossRef]

11. Van Essen, V.M.; Zondag, H.; Gores, J.C.; Bleijendaal, L.; Bakker, M.; Schuitema, R.; van Helden, W.G.J.; $\mathrm{He}, \mathrm{Z}$; Rindt, C.C.M. Characterization of $\mathrm{MgSO}_{4}$ hydrate for thermochemical seasonal heat storage. J. Sol. Energy Eng. 2009, 131, 041014. [CrossRef]

12. Boer, R.; Haije, W.; Veldhuis, J. Determination of structural, thermodynamic and phase properties in the $\mathrm{Na}_{2} \mathrm{~S}-\mathrm{H}_{2} \mathrm{O}$ system for application in a chemical heat pump. Thermochim. Acta 2002, 395, 3-49. [CrossRef]

13. Lahmidi, H.; Mauran, S.; Goetz, V. Definition, test and simulation of a thermochemical storage process adapted to solar thermal systems. Sol. Energy 2006, 80, 883-893. [CrossRef]

14. Zondag, H.; Kikkert, B.; Smeding, S.; Boer, R.; Bakker, M. Prototype thermochemical heat storage with open reactor system. Appl. Energy 2013, 109, 360-365. [CrossRef]

15. Ferchaud, J. Experimental Study of Salt Hydrates for Thermochemical Seasonal Heat Storage. Ph.D. Thesis, Technische Universiteit Eindhoven, Eindhoven, Netherlands, April 2016.

16. Kubota, M.; Matsumoto, S.; Matsuda, H. Enhancement of hydration rate of LiOH by combining mesoporous carbon for Low-temperature chemical heat storage. Appl. Therm. Eng. 2019, 150, 858-863. [CrossRef]

17. Yan, T.; Wang, R.; Li, T. Experimental investigation on thermochemical heat storage using manganese chloride/ammonia. Energy 2018, 143, 562-574. [CrossRef]

18. Sharma, R.; Kumar, E. Study of ammoniated salts based thermochemical energy storage system with heat up-gradation: A thermodynamic approach. Energy 2017, 141, 1705-1716. [CrossRef]

19. Stitou, D.; Mazet, N.; Mauran, S. Experimental investigation of a solid/gas thermochemical storage process for solar air-conditioning. Energy 2012, 41, 261-270. [CrossRef]

20. Zhong, Y.; Critoph, R.; Thorpe, R.; Tamainot-Telto, Z.; Aristov, Y. Isothermal sorption characteristics of the $\mathrm{BaCl}_{2}-\mathrm{NH}_{3}$ pair in a vermiculite host matrix. Appl. Therm. Eng. 2007, 27, 2455-2462. [CrossRef]

21. Li, S.; Huang, H.; Yang, X.; Bai, Y.; Li, J.; Kobayashi, N.; Kubota, M. Hydrophilic substance assisted low temperature $\mathrm{LiOH} \bullet \mathrm{H}_{2} \mathrm{O}$ based composite thermochemical materials for thermal energy storage. Appl. Therm. Eng. 2018, 706-711. [CrossRef] 
22. Li, S.; Huang, H.; Li, J.; Kobayashi, N.; Osaka, Y.; He, Z.; Yuan, H. The effect of 3D carbon nanoadditives on lithium hydroxide monohydrate based composite materials for highly efficient low temperature thermochemical heat storage. RSC Adv. 2018, 8, 8199-8208. [CrossRef]

23. Kurosawa, R.; Ryu, J. Effect of $\mathrm{LiOH}$ addition on dehydration reaction of $\mathrm{Mg}(\mathrm{OH})_{2}$. J. Chem. Eng. Japan 2019, 52, 152-158. [CrossRef]

24. Yang, X.; Li, S.; Huang, H.; Li, J.; Kobayashi, N.; Kubota, M. Effect of carbon nanoadditives on lithium hydroxide monohydrate-based composite materials for low temperature chemical heat storage. Energies 2017, 52, 644. [CrossRef]

25. Williams, D.; Miller, R. The Effect Water Vapor on the LiOH-CO ${ }_{2}$ Reaction. Part 1. Dynamic Isothermal System; Naval Research Lab: Washington DC, USA, 29 October 1969.

26. Kubota, M. Novel Techniques of Latent Heat Thermal Storage, Chemical Thermal Storage and Latent Heat Transportation; CMC Publishing: Tokyo, Japan, 2016; pp. 109-116. (In Japanese)

27. Pablo, J.; Aadersson, J.; Azoulay, M. Kinetic investigation of the sorption of water by lithium hydroxide. Thermochim. Acta 1987, 113, 87-94. [CrossRef]

28. Williams, D.; Miller, R. Effect of water vapor on the LiOH-CO2 reaction. Dynamic isothermal system. Ind. Eng. Chem. Fundam. 1970, 9, 454-457. [CrossRef]

(C) 2019 by the authors. Licensee MDPI, Basel, Switzerland. This article is an open access article distributed under the terms and conditions of the Creative Commons Attribution (CC BY) license (http://creativecommons.org/licenses/by/4.0/). 